\title{
フィードフォワード型能動制御による重機騒音の低減効果 THE REDUCTION EFFECT OF CONSTRUCTION MACHINERY NOISE BY FEEDFORWARD TYPE ACTIVE NOISE CONTROL
}

\author{
金澤朗蘭*, 安井健治**, 柳沼勝夫*** \\ Laura KANAZAWA, Kenji YASUI and Katsuo YAGINUMA
}

\begin{abstract}
We developed an active noise control (ANC) system which could be operated stably to the noise of moving (working) machineries. To the ANC system, we applied the feedforward control method with reference signal and without $\hat{\mathrm{C}}$. The control method estimated a predominant frequency in time domain and calibrated the phase delay. We checked the ANC by numerical simulation and laboratory experiment. The results are as follows.

1. By the numerical simulations, we confirmed the proposed method performed more stably and had the shorter convergence time of calibration, than the methods of general feedforward control and general feedback control.

2. Through laboratory experiments, we confirmed the ANC system with the proposed control method reduced the noise of construction machinery by about $10 \mathrm{~dB}$.
\end{abstract}

Keywords : Active Noise Control, Construction machinery noise, Feedforward control, F eedback control アクティブ・ノイズ・コントロール, 建設機械騷音, フィードフォワード制御, フィ ードバック制御

\section{1. はじめに}

建設現場では、使用する建設機械、特に重機から、低周波数帯域 の音を主成分とする騷音が発生する場合が多い。この騒音には、エ ンジンの回転数に応じて、他の周波数よりも突出して音圧が高い周 波数（以下、卓越周波数と記す）が存在する。また、卓越周波数は $100 \mathrm{~Hz}$ 以下である場合が多い。ヒトの聴覚は低い周波数の音ほど聞 こえにくいという特性をもつため、建設現場など様々な周波数の音 が混在する場所では中〜高音域における周波数の音がよく聞こえる。 しかし、空や壁によって中〜高音域の周波数の音が大幅に遮断され るため、屋内では低周波数の音の影響が大きくなる。さらに、低周 波数の音は、防音塀や防音壁を設置しても、回折や透過のため効果 的に音圧を低減するのが難しい1)。

これらの重機から発生する低周波数の騒音の対策方法として、パ ッシブ手法とアクティブ手法の 2 つの方法がある。パッシブ手法を 使用した重機騒音対策として、干涉を利用した方法がある 2)。この 方法では、重機の騒音源である排気筒へ、側面に枝ダクト（サイド ブランチ）を設けたマフラー（消音器）を設置する。サイドブラン 于の長さは卓越周波数の波長の $1 / 4$ の長さ $(\lambda / 4 、 \lambda=\mathrm{c} / \mathrm{f} 、 \lambda$ : 波長 $[\mathrm{m}]$ 、 $\mathrm{c}$ :音速 $[\mathrm{m} / \mathrm{s}] 、 \mathrm{f}$ : 周波数 $[\mathrm{Hz}])$ とすることで、排気筒からマフラー内
を伝搬する低周波音と、この低周波音と逆位相となるサイドブラン チからの反射音を干渉させることで、マフラー内の音圧が低減する。 パッシブ手法では、マフラーにより騒音源である排気筒を囲うため、 確実に騒音を低減できる。しかし、サイドブランチの長さが固定で あるため、卓越周波数が変動する場合には効果が得られない可能性 がある。

アクティブ手法を使用した重機騒音対策には、アクティブ・ノイ ズ・コントロール（Active Noise Control、以下 ANC と記す）があ る。ANC とは、対象とする騒音を低減するため、騒音と逆位相の音 をスピーカから出力して干涉させるものであり、重機騷音対策に適 用寸るケースが近年増えている ${ }^{344) 5}$ 。 の近傍において騒音とスピーカからの制御音を干渉させることで、 騷音源である排気筒の近傍の音圧を低減している。

一般的な ANC の制御方法として、Fig.1 および Fig.2 に示すよう なフィードフォワード型（以下、FF 型と記す）とフィードバック 型（以下、FB 型と記す）がある。図中の $\mathrm{h} 、 \mathrm{C}$ は、実際の音響系の 伝達特性を示寸。また $\hat{\mathrm{h}} 、 \hat{\mathrm{C}}$ はそれぞれの伝達特性を同定したフィ ルタである。FF 型の制御では、参照信号と誤差信号を観測し、誤 差信号が最小となるよう、 $\hat{\mathrm{h}}$ を更新する。 $\mathrm{FB}$ 型は、FF型と同様の

\footnotetext{
* (株)奥村組技術研究所建築研究グループ 主任研究員・修士(芸術工学)

** (株)奥村組技術研究所企画管理グループ 企画チームリーダー

*** 株)奥村組技術研究所建築研究グループ 主任研究員・修士 (工学)
}

Senior Research Engineer, Architectural Research Division, Technical Research Institute, Okumura Corporation, M.Art Eng.

Planning Team Leader, Plans and Management Division, Technical Research Institute, Okumura Corporation

Senior Research Engineer, Architectural Research Division, Technical Research Institute, Okumura Corporation, M.Eng. 
方法で $\hat{\mathrm{C}} 、 \hat{\mathrm{h}}$ を同定するが、参照信号を観測しないため、誤差信号 から制御音を差し引いたものを参照信号としている。フィルタ係数 の更新方法として、ANCでは一般的な Filtered-X-LMS (LMS:Least Mean Square、最小二乗平均) の適応アルゴリズム6)を用いる場合 が多い。

Fig. 1 および Fig.2 の制御方法には、二次音源である制御スピーカ から音圧の低減位置である誤差マイクまでの伝達関数 C をモデル化 した $\hat{\mathrm{C}}$ が含まれている。アナログの伝達関数 C をデジタルフィルタ にするため、 $\hat{\mathrm{C}}$ には量子化誤差等によるモデル化誤差が生じており、 $\hat{\mathrm{C}}$ のモデル化誤差によってシステムが不安定になる可能性がある。 このため、 $\mathrm{C}$ をたない ANC システムとして、回転パルスなどの 信号から騒音の基本周期を観測して参照信号とし、さらに誤差信号 を観測して制御音を生成するシステム 7)や、制御フィルタ（Fig.1 および Fig.2 中の h に相当）に摂動を与えることにより、制御フィ ルタを更新するアルゴリズム（摂動法）8）な゙゙、様々なアルゴリズ ムが提案されている。

重機の排気筒周囲に参照信号用と誤差信号用の 2 本のセンサを設 置すると、特に誤差信号用のセンサが周囲へ接触しないよう建設現 場内の移動や作業上の旋回の動作を制限する必要があり、実現が難 しい。このため、上記のアルゴリズムを適用した ANC システムは、 これまで重機のように移動・旋回する音源には適用できなかった。 また、建設現場では様々な騒音が混在するため、入力が誤差信号の みでは、着目した騒音以外の影響が大きくなり、効果が十分に得ら れない可能性がある。

そこで著者らは、移動する騒音源に設置でき、様々な騒音が混在 する場合でも安定に制御可能な ANCシステムの開発を目的として、 参照信号のみを用いる、 $\mathrm{C}$ を持たない $\mathrm{FF}$ 型の制御方式の適用性を 検討した。本報では、このシステムについて述べる。

\section{2. 提案の制御方式を適用したANC システムの概要}

重機から発生する $100 \mathrm{~Hz}$ 以下の卓越周波数の音圧を低減するた めの騒音対策として、ANC は効果的である。ANCにより重機騷音 の卓越周波数の音圧を低減するためには、重機の作業による卓越周 波数の変動に追従して、逆位相の音波をスピーカから出力し干渉さ せる必要がある。提案の制御方式 (以下、提案型と記す) は FF 型 を基本としているが、一般的な $\mathrm{FF}$ 型と異なり音響系のフィードバ ック処理を含まない。そのため、システムの入力/出力で発生する振 幅比や位相差をシステム上で解消寸る必要があるが、FFTによる周 波数領域での処理では、それ自体が時間遅れを生じさせる。そこで、 提案の制御方法では時間領域において、システム全体の振幅比と位 相差を解消寸る。

提案型のブロックダイヤグラムを Fig. 3 に示す。制御による効果 を向上させるため、参照マイクで観測した信号にバンドパスフィル タ（Fig.3 中の BPF）を適用し、参照マイクで観測した信号から卓 越周波数を含む範囲のみを抽出し処理対象としている。さらに、重 機の作業によって卓越周波数は変動するため、バンドパスフィルタ を透過した信号の卓越周波数をLMSアルゴリズムにより推定する。 推定した卓越周波数の情報をもとに、後述する振幅・位相補正を行 い卓越周波数の信号と逆位相の信号を生成して制御スピーカより 出力する。なおバンドパスフィルタは、重機の各作業時の卓越周波

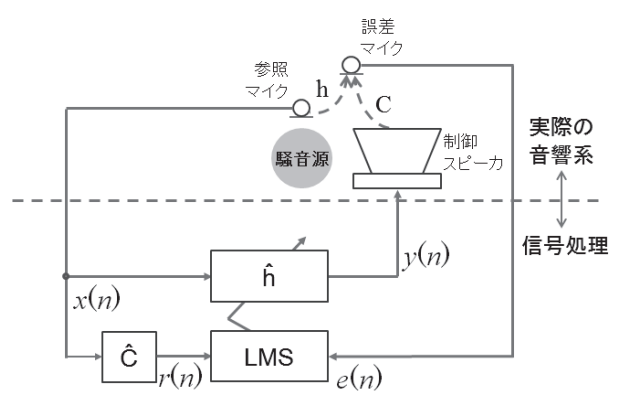

Fig.1 The feed forward control system of conventional ANC

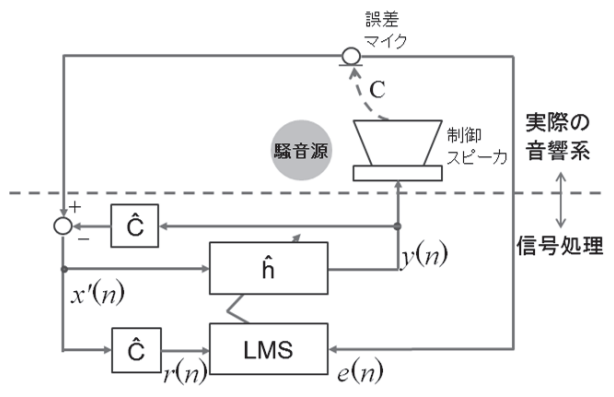

Fig.2 The feed back control system of conventional ANC

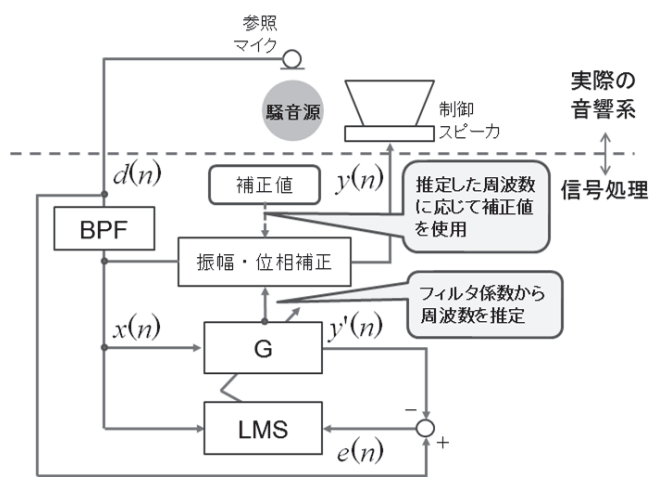

Fig.3 Proposed control method

数がバンドパスフィルタの範囲内となるよう下限周波数と上限周波 数を決めた、チェビシェフフィルタである。

提案型の ANC システムの入力/出力には、バンドパスフィルタ、 スピーカ、アンプ等によって振幅比および位相差が生じる。これら の振幅比や位相差は周波数特性をもつ。そこで、まずシステム（参 照マイクから制御スピーカまで、以下同様）の振幅比と位相差を測 定し、これらの差を解消寸るための補正值を周波数ごとに算出する。 算出した各周波数に対応寸る補正值のデータはシステムに組み込ま れ（Fig.3 中の振幅・位相補正に相当）、LMS による卓越周波数の 同定結果に応じ、補正值を取り出して出力信号に加え、振幅比と位 相差を修正する。

\section{3. 提案する制御方法}

\section{1 振幅比および位相差の補正值}

提案型の ANC システムでは、適用する重機の騒音特性に合わせ てスピーカやアンプなどの機器の選定を行い、さらにバンドパスフ イルタを設計する。このため、システムの入力/出力における振幅比 および位相差は、対象とする重機騒音ごとに異なる。システムの入 


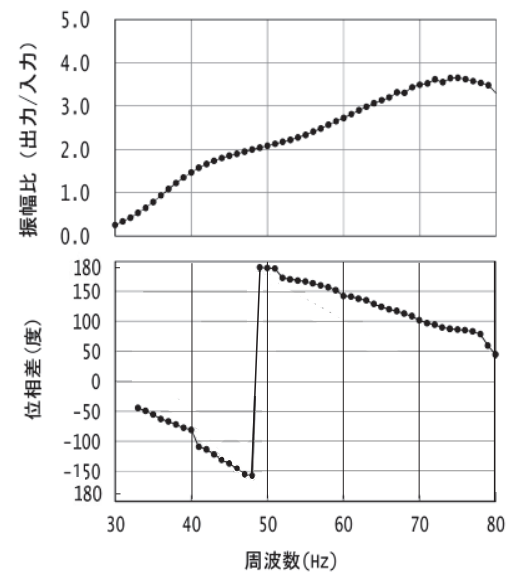

Fig.4 An example of an amplitude ratio and a phase differences of control speaker

力/出力における振幅比および位相差の一例を Fig.4 に示す。振幅比 に着目寸ると、例では周波数が高くなるほど振幅比が大きくなって おり、入力に対して出力が大きい特性であることがわかる。また位 相差は、周波数が高くなるにつれ大きくなっている。この振幅比お よび位相差をもとに、振幅比が 1、位相差がゼロとなる補正值を算 出し、システムに組み込む。Fig.4 の例では、 $48 \mathrm{~Hz}$ において振幅比 2、位相差が- $160^{\circ}$ であるため、振幅の補正值は $1 / 2$ 、位相の補正值 は+160となる。

\section{2 時間領域における周波数の同定}

ANC における制御は、Filtered-X-LMS を用いて FF 型または FB 型の適応制御を行うのが一般的である。上記の制御方法では誤差信 号を使ってフィルタ係数を更新する。これに対し、提案する制御方 法では、Filtered-X-LMS と同様に LMS アルゴリズムを使用し、入 力信号である参照信号と、バンドパスフィルタをかけた参照信号の 差を最小化するためのフィルタ係数を更新する。最適化したフィル 夕係数から、重機騷音の卓越周波数が同定可能となる 910)。

まず、角周波数 $\omega$ の純音を対象に, 複素表現の LMS アルゴリズ ムについて述べる。Fig.3 より、入力信号と出力信号の差である誤 差信号は

$$
\mathrm{e}(\mathrm{n})=\mathrm{d}(\mathrm{n})-y^{\prime}(\mathrm{n})
$$

$$
=d(n)-G(n) x(n)
$$

となる。ここに、 $\mathrm{n}$ は正の整数、 $\mathrm{d}(\mathrm{n})$ は入力信号、 $\mathrm{y}^{\prime}(\mathrm{n})$ はフィルタ の出力信号、 $G(n)$ はフィルタ係数、 $x(n)$ はフィルタへの入力信号で ある。 $\mathrm{n}$ から $\mathrm{n}+1$ へのフィルタ係数は

$$
\mathrm{G}(\mathrm{n}+1)=\mathrm{G}(\mathrm{n})+2 \mu e(\mathrm{n}) \bar{x}(\mathrm{n})
$$

となる。これは最急降下法の収束式である。ここで、 $\bar{x}(\mathrm{n})$ は $\mathrm{x}$ の複 素共役、 $\mu$ はステップサイズパラメータと呼ばれる正の定数である。 上式が LMS アルゴリズムと呼ばれており、現在の值から、次のフ イルタ係数を同定する。

次に、フィルタ係数から周波数を同定する方法を示す。フィルタ への入力音圧 $x(n T)$ を以下のように定義する。

$$
\begin{aligned}
\mathrm{x}(\mathrm{nT}) & =\mathrm{A} \exp (i \omega n T) \\
& =\alpha_{\mathrm{R}}(\mathrm{nT}) \cos \omega(\mathrm{nT})-i \alpha_{1}(\mathrm{nT}) \sin \omega(\mathrm{nT}) \mathrm{nT} \\
\mathrm{A} & =\left(\alpha_{\mathrm{R}}{ }^{2}+\alpha_{1}{ }^{2}\right)^{1 / 2}
\end{aligned}
$$

ここで、 $\alpha_{R}(n T) 、 \alpha_{1}(n T)$ は、フーリエ級数の実部虚部、 $\omega$ は同定す

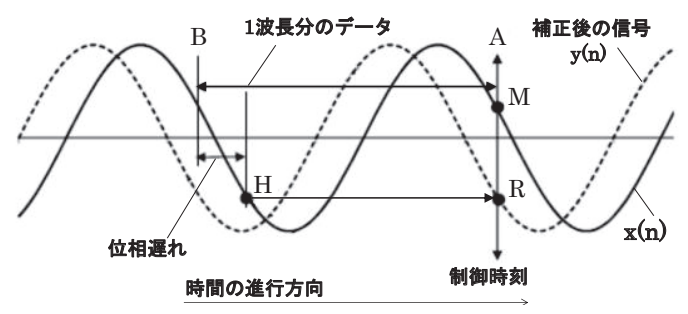

Fig.5 The way of phase correction

る角周波数 $(\omega=2 \pi f) 、 \mathrm{~T}$ はサンプリング周期である。式(1)を式 (2) に代入すると、

$\mathrm{G}(\mathrm{n}+1)=(1-2 \mu) \mathrm{G}(\mathrm{n})+2 \mu d(\mathrm{n}) \bar{x}(\mathrm{n})$

同様に

$\mathrm{G}(\mathrm{n})=(1-2 \mu) \mathrm{G}(\mathrm{n}-1)+2 \mu d(\mathrm{n}-1) \bar{x}(\mathrm{n}-1)$

式(5)を式(4)に代入すると

$\mathrm{G}(\mathrm{n}+1)=(1-2 \mu)^{2} \mathrm{G}(\mathrm{n}-1)+2 \mu \sum_{l=0}^{1}(1-2 \mu)^{\prime} \mathrm{d}(\mathrm{n}-1) \bar{x}(\mathrm{n}-1)$

これを繰り返すと、G(0)=0 より式(6) は以下となる。

$\mathrm{G}(\mathrm{n}+1)=2 \mu \sum_{l=0}^{1}(1-2 \mu)^{\prime} \mathrm{d}(\mathrm{n}-\mathrm{l}) \bar{x}(\mathrm{n}-\mathrm{l})$

次に、入力信号 $d(n)$ を以下のように定義する。

$\mathrm{d}(\mathrm{n})=\sum_{k=0}^{K-1} \frac{A_{k}}{2} \exp \left(i \omega_{\mathrm{k}} \mathrm{n} T+\theta_{\mathrm{k}}\right)+=\sum_{k=0}^{K-1} \frac{A_{k}}{2} \exp \left(-i \omega_{\mathrm{k}} \mathrm{nT}-\theta_{\mathrm{k}}\right)$ ここで、 $\omega_{\mathrm{k}}$ は周波数である。式(3) と式(8)を式(7)に代入し、等比 級数の和の公式を利用して整理すると、 $G(n+1)$ は以下となる。

$$
G(n+1)=\frac{2 A \mu \exp \{i(\bar{\omega}-\omega) n T+i \theta\}}{1-(1-2 \mu) \exp \{-i(\bar{\omega}-\omega) n T\}}
$$

ここで、のは周波数の真值、 $\omega$ は同定值である。また、A および $\theta$ は初期振幅および初期位相である。上式より、

$$
\begin{aligned}
& \frac{G(n+1)}{G(n)}=\exp \{i(\bar{\omega}-\omega) T\} \\
& \cos (\bar{\omega}-\omega) T+i \sin (\bar{\omega}-\omega) T=\frac{G(n+1)}{G(n)}
\end{aligned}
$$

となる。したがって、次の式より周波数を推定できる。

$$
\omega((n+1) T)=\omega(n T)+\frac{1}{T} \arg \left[\frac{G(n+1)}{G(n)}\right]
$$

式(12) の $\omega((n+1) T)$ が、実時間での同定された周波数になる。

\section{3 位相特性の実時間補正方法}

システム全体の振幅比および位相差は、事前にスイープ信号を用 いた試験を行うなどして求めることができる。位相差の補正方法を Fig.5 に示す。Fig.5 の実線は制御コントローラおよびバンドパスフ イルタの位相特性を含んだ信号 $\mathrm{x}(\mathrm{n})$ 、破線は補正後の信号 $\mathrm{y}(\mathrm{n})$ であ る。また、 $\mathrm{A}$ を制御時刻、 $M$ 点は制御時刻の $x(n) 、 R$ 点は制御時 刻における $\mathrm{y}(\mathrm{n})$ である。補正方法は次の通りである。

i . 周波数推定結果 $(\omega)$ から、位相補正を行う周波数を決定する

ii. 1 波長分のデータ数 $\mathrm{Nw}$ を $\mathrm{Nw}=1 /(\mathrm{f} \cdot \mathrm{T})$ として求める(f : 周波数 $[\mathrm{Hz}])$

iii. 制御時刻から 1 波長分の計測データを記憶する

iv. 予め計測した、周波数の位相補正值を取り出す

$\mathrm{v}$. 位相遅れに相当するデータ数 $\mathrm{N} \varphi$ を $\mathrm{N} \varphi=\mathrm{Nw} \varphi /(2 \Pi)$ $(\varphi$ : 位相補正值 $[\mathrm{rad}])$ とする

vi . 1 波長分のデータ数から位相遅れに相当するデータ数を引い 


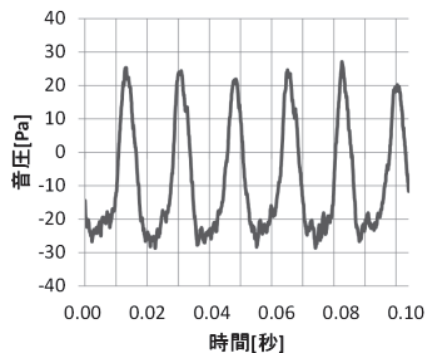

(a) Time series waveform

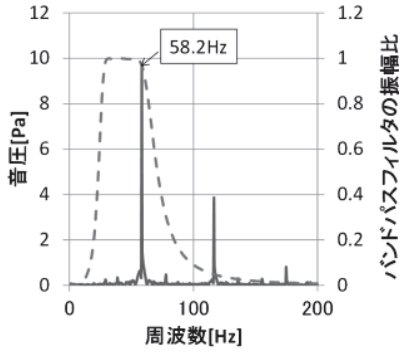

(b)Freqency characteristic
Fig.6 Characteristic of the noise

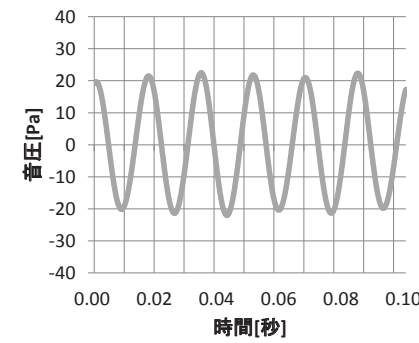

Fig.7 Filter output signal

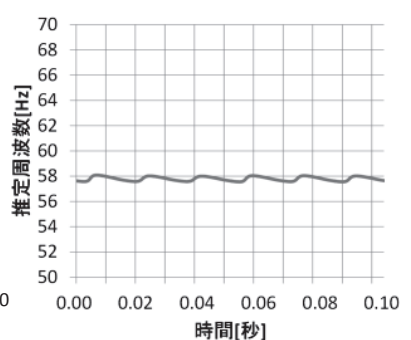

Fig.8 Identification frequency

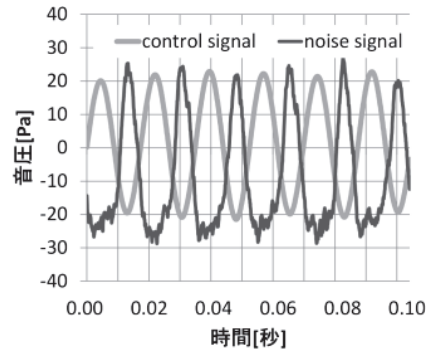

Fig.9 Phase corrected signal

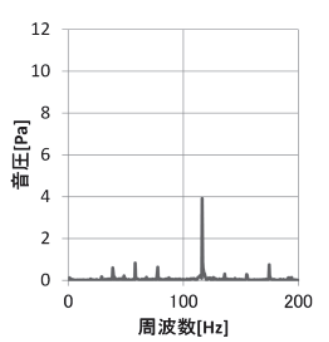

Fig.10 Control effect
て、 $\mathrm{N}_{\mathrm{MH}}=\mathrm{Nw}-\mathrm{N} \varphi$ を求める

vii. 記憶した 1 波長分のデータの中から、制御時刻よりデータ数

$\mathrm{N}_{\mathrm{MH}}$ 前のデータ $\mathrm{H}$ をとり出し、補正後のデータ $\mathrm{R}$ とする

以上の i 〜 vii を各制御ステップごとに実行することで、時間領域に おいて位相補正を行うことができる。

\section{4 提案の制御方法による制御効果}

シミュレーションにより、提案した周波数の同定方法と位相補正 方法によって生成した制御信号が、騒音と同振幅・逆位相となって いることを確認した。Fig.6 に、シミュレーションに用いた騒音の 特性を示す。Fig.6(a)の時系列波形は正弦波に近い形を示しており、 この騒音が単一の周波数成分の影響が強いことがわかる。また、 Fig.6(b)の周波数特性より、この騒音は $58 \mathrm{~Hz}$ 付近にピークをもって おり、この周波数が卓越周波数であることがわかる。

Fig.6(b)中に、シミュレーションで用いたバンドパスフィルタの 特性を示す。卓越周波数である $58 \mathrm{~Hz}$ 付近がバンドパスフィルタの 通過帯域内であること、また、約 $100 \mathrm{~Hz}$ 以上の周波数におけるピー クの音圧を十分に低減できる特性であることがわかる。Fig.7 に、 Fig.6 に示した特性をもつバンドパスフィルタを透過した時系列波 形を示寸。Fig.6(a)における高周波数の成分が消え、より正弦波に 近い波形となったことがわかる。また、バンドパスフィルタを適用
Table1 The control methods and those's convergence time

\begin{tabular}{|c|c|c|c|c|}
\hline & \multicolumn{3}{|c|}{ 収束時間[sec] } \\
\hline \multicolumn{2}{|c|}{ 入力信号:振幅1(0-P) } & F F 型 & F B型 & 提案型 \\
\hline \hline \multirow{4}{*}{ 正弦波 } & $50 \mathrm{~Hz}$ & 0.0435 & 0.0462 & 0.0497 \\
\cline { 2 - 5 } & $60 \mathrm{~Hz}$ & 0.0448 & 0.0551 & 0.0473 \\
\cline { 2 - 5 } & $70 \mathrm{~Hz}$ & 0.0396 & 0.0614 & 0.0442 \\
\cline { 2 - 5 } & $80 \mathrm{~Hz}$ & 0.0354 & 0.0604 & 0.0405 \\
\cline { 2 - 5 } & $90 \mathrm{~Hz}$ & 0.0319 & 0.0550 & 0.0363 \\
\cline { 2 - 5 } & $100 \mathrm{~Hz}$ & 0.0286 & 0.0534 & 0.0328 \\
\hline \multirow{4}{*}{ 正弦波 } & $40-50 \mathrm{~Hz}$ & 0.0334 & 0.0352 & 0.0395 \\
\cline { 2 - 5 } 变動 & $40-60 \mathrm{~Hz}$ & 0.0365 & 0.0398 & 0.0390 \\
\cline { 2 - 5 } & $40-70 \mathrm{~Hz}$ & 0.0325 & 0.0475 & 0.0370 \\
\cline { 2 - 5 } & $40-80 \mathrm{~Hz}$ & 0.0337 & 0.0482 & 0.0340 \\
\cline { 2 - 5 } & $40-90 \mathrm{~Hz}$ & 0.0300 & 0.0482 & 0.0306 \\
\cline { 2 - 5 } & $40-100 \mathrm{~Hz}$ & 0.0242 & 0.0435 & 0.0277 \\
\hline
\end{tabular}

したことにより、位相が約 $90^{\circ}$ 、ずれたことがわかる。Fig.7 に示 した時系列波形の周波数同定結果を Fig. 8 に示寸。同定された周波 数は約 $58 \mathrm{~Hz}$ で、Fig.6(b)の約 $58 \mathrm{~Hz}$ のピークと一致しており、適 応フィルタによって良好に周波数の同定ができたことを確認した。

Fig.9 に Fig.7 に示した信号を位相補正した結果と、併せて Fig.6(a) に示した元の音圧波形を示寸。位相補正後の音圧波形は、元の波形 と逆位相になっていることが確認できる。Fig.10 に、Fig.9 に示し た 2 つの信号を足し合わせた信号の周波数特性を示す。高周波成分 が残っているものの、約 $58 \mathrm{~Hz}$ の周波数における音圧が低減され、 制御によって対象の音圧が低減できたことがわかる。

\section{4. 制御の安定性および騒音の低減効果 \\ 4.1 同定時間と制御の安定性の比較}

Fig.3 に示した提案型の制御方法と、一般的な FF 型の制御方法 および FB 型の制御方法について、出力信号 $\mathrm{y}(\mathrm{n})$ の同定に必要な時 間（以下、同定時間と記す）の違いを確認した。音源は正弦波とし、 周波数が変動せず一定の場合と、周波数が変動する場合について、 同定時間をシミュレーションした。

Table1 に、シミュレーションを行った入力信号の一覧と同定時間 を示す。なお、それぞれの制御型のシミュレーション方法は、Fig.1 Ｆig.3 に示すブロックダイヤグラムのものとした。また、シミュ レーションを行ったノート PC の動作周波数は $1.8 \mathrm{GHz}$ であった。 ブロックダイヤグラム中の伝達特性 $\hat{\mathrm{h}} 、 \hat{\mathrm{C}}$ はそれぞれ実測により求 めた h、C と同等の特性とし、特性を十分に反映できる次数とした。 サンプリング周波数は、音波の 1 波長を 64 分割以上（位相差 5.6 度以下）でモデル化することを想定し、400Hz までの音に適用する ために $25,600 \mathrm{~Hz}$ とした。ステップサイズ $\mu$ は制御が発散しない最 大の值とし、 $\mathrm{FF}$ 型 : $\mu=0.001 、 \mathrm{FB}$ 型 $: \mu=0.001$ 、提案型 $: \mu=0.01$ を用いた。同定時間は、制御の開始時刻から出力信号 $\mathrm{y}(\mathrm{n})$ が収束す るまでのデータ数を、サンプリング周波数で除した值を同定時間と した。収束は、干涉後の振幅（FF 型および FB 型は Fig.1 および Fig.2 における e(n)、提案型は Fig. 3 における d(n)+y(n)をさす) が、 初めて基準音圧に相当する $2 \times 10^{-5}$ 11)未満となる時点とした。また、 周波数が変動する音源を用いた場合、変動直後の時点を制御の開始 時点として同定時間を算出した。

音源の種類によって、各制御型の同定時間の傾向は大きく変わら なかった。 $\mathrm{FF}$ 型は他の制御型に比べて同定が速く、また周波数が 高くなるにつれ同定時間が短くなった。これは、他の制御型と異な り、LMS に入力する信号がともに観測信号であり（Fig.1 中の r (n) と $\mathrm{e}(\mathrm{n})) 、 \mathrm{e}(\mathrm{n})$ をシステム内で作成する必要がないため、速く収束で 


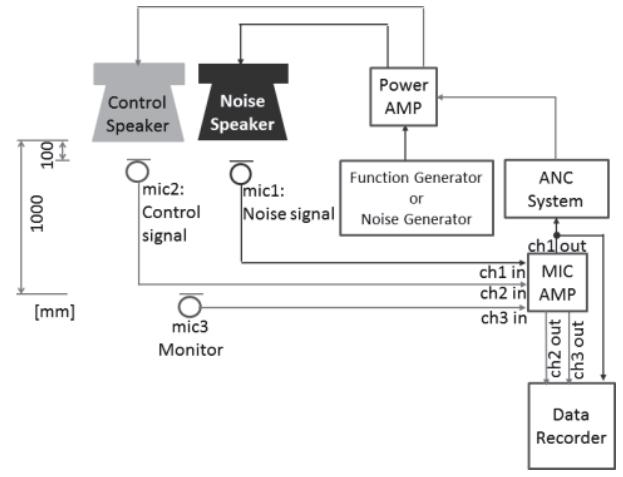

Fig.11 Block diagram of the experiment

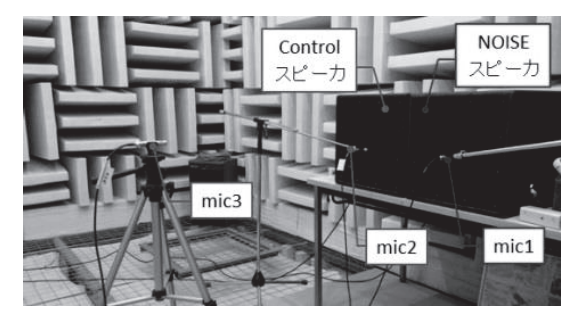

Photo1 Condition of the experiment

きると考えられる。また周波数が高くなると波長が短くなるため、 同じ波数を処理するのにかかる時間が短くなり、収束が速くなった と考えられる。FB型は、他の制御型と比較して若干同定が遅く、 また周波数が高くなるにつれて同定時間が長くなる傾向があった。 FB 型の制御では、フィルタ係数への入力信号を、ひとつ前のフィ ルタの出力信号から算出するため、わずかな誤差が生じやすい。こ のため、誤差を解消寸るための計算に時間を要したものと考えられ る。提案型は、音源が $60 \mathrm{~Hz}$ 以下の場合を除き、同定時間が FB 型 よりも短く $\mathrm{FF}$ 型より長い傾向を示した。また、 $\mathrm{FF}$ 型と同様、周波 数が高くなるにつれ同定時間が短くなった。これは、周波数が高い ほど波長が短いため、周波数の同定時間が短くなったためと考えら れる。

シミュレーションにより、制御が発散しない $\mu$ の值において、提 案型の制御方法は、その他の制御方法よりも大きな $\mu$ の值で発散せ ずに安定した制御が可能であることが分かった。 $\mu$ の值が異なるた め同定時間の単純比較はできないが、より大きな $\mu$ を使用しても安 定して制御できたことから、FB 型よりも提案型の方が安定性が高 いといえる。また、観測点の数を考慮すると、FF 型の制御方法と 比較して移動音源に対し十分に適用可能であることが分かった。

\section{2 騷音の低減効果}

シミュレーションでは他の制御方法との相対的な性能比較を行い、 提案型の制御方法の有用性を確認した。次に、提案した制御方法に よる $\mathrm{ANC}$ システムにより、制御によって効果が得られるまでの時 間と、低減量を実験室で確認した。実験ブロックダイヤグラムを Fig.11に示す。騒音を発生させる騒音用のスピーカ : Noise Speaker、 制御音を出力する制御用のスピーカ：Control Speaker、参照信号 を観測するマイク：mic1、制御信号を観測するマイク：mic2、制御 効果を確認するマイク： mic3 を Fig.11 および Photo1のように構 成した。また、各マイクへの入力音をデータレコーダに収録した。 サンプリング周波数は $25,600 \mathrm{~Hz}$ である。 $\mathrm{ANC}$ システム $(\mathrm{PC})$ の
Table2 The noises used in the experiment
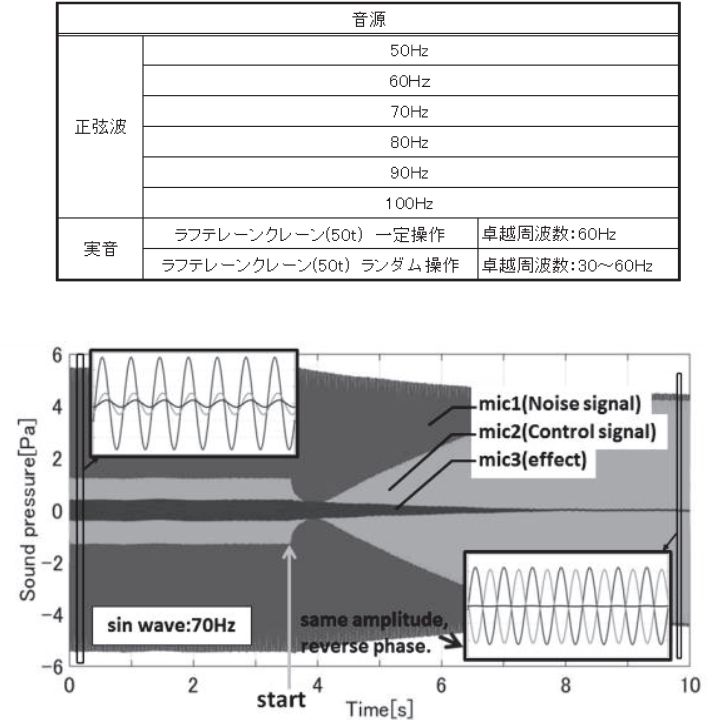

Fig.12 An example of sound pressure under control

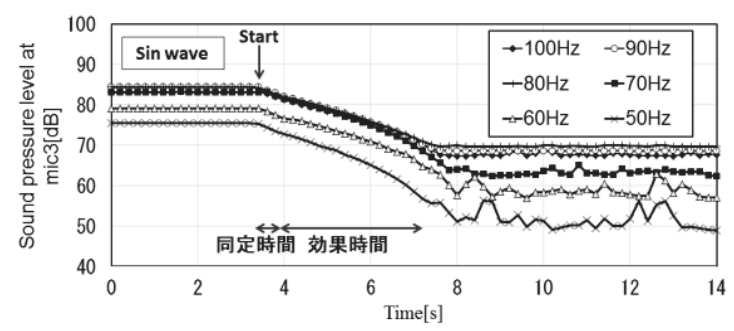

Fig.13 The sound pressure level under control

動作周波数は $3.6 \mathrm{GHz}$ であった。 $\mu$ はシミュレーションによる検討 と同じ 0.01 とした。騒音として用いた音源の一覧を Table 2 に示す。 シミュレーションの場合と同様に正弦波と、実際にラフテレーンク レーンの排気筒近傍で収録した実音を用いた。なお、実験に用いた ラフテレーンクレーン騒音の卓越周波数は、エンジン回転数が一定 となる操作のとき約 $60 \mathrm{~Hz}$ 、エンジン回転数がランダムに変化する ときは $30 〜 60 \mathrm{~Hz}$ だった。

音源に正弦波を用いた場合の結果の一例として、70Hz の場合の mic1,mic2,mic3 で観測された音圧振幅を Fig.12 に示す。制御開始 から 0.3 秒程度で周波数の同定が終わり（同定時間）、その後制御に よる効果が現れはじめた (効果時間)。同定時刻から約 4 秒程度で、 mic1,mic2 における音圧は同振幅、逆位相となり、mic3 で観測され る音圧の振幅が低減して制御効果を確認した。Fig.13に、各正弦波 を音源とした場合の、制御開始から同定までの mic3 における音圧 レベルの変化を示す。提案型の制御方法を用いた ANCにより mic3 の位置で $13 \sim 25 \mathrm{~dB}$ 程度の効果を示した。制御開始から同定までの 時間は、周波数が高くなるにつれ若干短くなるものの、どの周波数 の場合でも $0.3 \sim 0.5$ 秒程度を要した。シミュレーションでは PC 内 の処理のみであるが、実際のシステムでは AD-DA 変換などの処理 が加わるため、シミュレーションよりも同定時間が長くなることが 予想された。しかし、PC の処理能力が高いため、実際には同定時 間のシミュレーションとの差は小さくなった。ただし、周波数が高 くなると同定時間が短くなる傾向は、シミュレーションと同様であ 


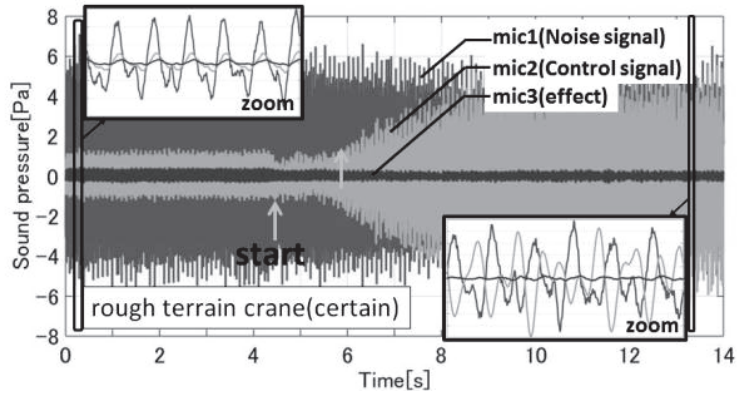

Fig.14 The sound pressure under control

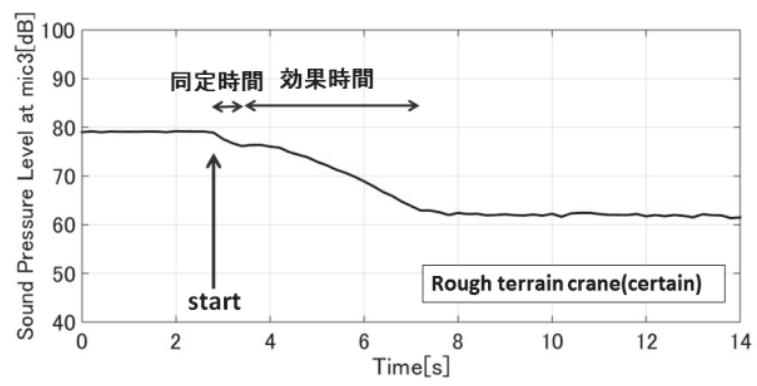

Fig.15 The sound pressure level under control

った。

Fig.14に、音源にラフテレーンクレーンからの騒音を用いた場合 の、mic3における音圧振幅を示す。なお、この時用いた騒音は、卓 越周波数の変動が小さい作業の時の、ラフテレーンクレーン排気筒 付近における収録音である。卓越周波数の変動が小さいこともあり、 音源に正弦波を用いた場合と同様 4 秒程度で mic3 における音圧が 低減した。Fig.15に、Fig.14の mic3 における音圧変化をレベル化 したものを示す。制御により $10 \mathrm{~dB}$ 程度の低減効果を確認した。

Fig.16に、音源にラフテレーンクレーンからの騒音を用いた場合 の、制御開始から収束までの mic3 における音圧レベルの変化を示 す。なお、この時用いた騒音は、卓越周波数の変動が大きな作業の 時の、ラフテレーンクレーン排気筒付近における収録音である。卓 越周波数の同定には 0.5 秒程度かかるため、騒音が急激に変動した 直後には制御により一部音圧が増幅したが、 1 秒以上卓越周波数が 継続する場合には、制御効果により最大 $10 \mathrm{~dB}$ 程度、音圧が低減し た。Fig.17 に、各マイク位置における音圧振幅の一部(Fig.16 に示 した音圧振幅の範囲)を示す。mic1、mic2 における音圧はほぼ同振 幅、逆位相となっているのが確認できた。

\section{5. おわりに}

時間領域における周波数の推定方法と、考案した位相遅れの補正 方法を、重機騒音対策用の ANC に適用した。シミュレーションお よび実験により、提案した制御方法が、FF 型および FB 型と比較し て安定で、同定時間が短くなることを確認した。結論は以下のとお りである。

・実時間での周波数推定方法と位相補正方法を適用した提案型制 御方法と、一般的な FF 型制御方法および FB 型制御方法を使用 した場合の計算安定性と収束時間を比較したところ、提案型は従 来の制御方法よりも、安定で同定時間が短くなることを確認した。

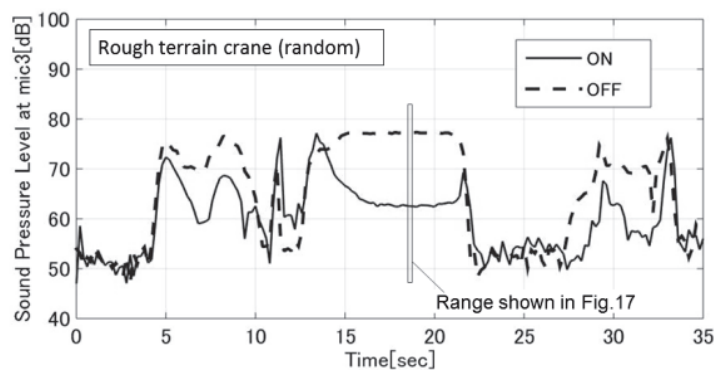

Fig.16 The comparison of sound pressure level

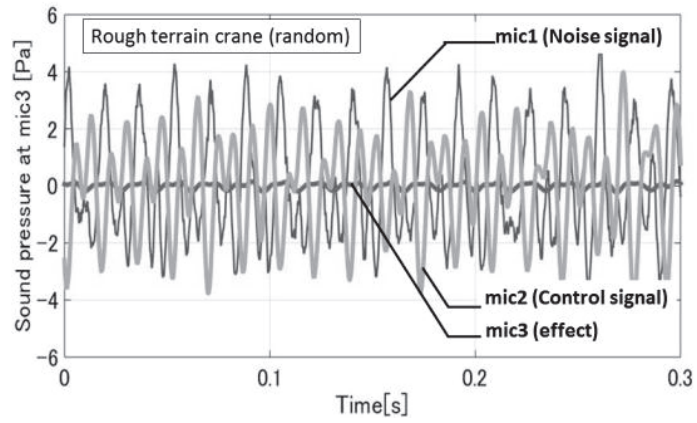

Fig.17 The sound pressure under control

・提案型の制御方法を適用した ANCにおいて、音源が正弦波の場 合には同定時間が 0.5 秒以下になり、制御効果は $20 \mathrm{~dB}$ 以上得ら れることを実験室で確認した。音源が収録した重機騒音であり卓 越周波数変動する場合でも、一定の周波数が 1 秒以上継続する場 合には、最大 $10 \mathrm{~dB}$ 程度の低減効果が得られた。

$10 \mathrm{~dB}$ の騒音低減は実用上、効果的であると考えられる。今後は、 実機に ANC システムを適用し、効果を確認していきたい。

\section{参考文献}

1)環境省「よくわかる低周波音」5低周波音を防止するには, <http://www. env.go.jp/air/teishuha/yokuwakaru/05.pdf >(参照 2016.1.30)

2)山田, 藤橋：サイドブランチ型消音器による建設機械騒音の低減 その 3 バ ックホウへの適用範囲拡大, 日本建築学会大会学術講演梗概集, 環境工学 I, pp193 194,2015,9

3)松岡,小林,半田,鈴木：ANC を用いた建設機械騒音に関寸る実験的検討, 日本建築学会大会学術講演梗概集, 環境工学 I, pp.227〜 228, 2008.9 4)漆戸，阿部：建設重機が発生する低周波音のアクティブコントロールによ る制御，フジタ技術研究報告第 49 号, 2013.11

5）内野，宮崎，井上,石橋,吉岡：重機等の排気低周波音低減用アクティブ消 音器の開発, 佐藤工業技術研究所報第 39 号, pp.75 78, 2014.12

6)西村,宇佐川,伊勢:アクティブノイズコントロール, 日本音響学会編, コロナ 社,p.75, 図 3.3,2006.7

7）大沼,小沼,杉村,西村:波形同期法によるディーゼルエンジンの排気音のア クティブコントロール, 日本舶用機関学会誌第 27 巻第 4 号,pp.337〜 $342,1992.4$

8）梶川,野村： 2 次経路モデルを必要としないアクティブノイズコントロール システム，電子情報通信学会論文 A，基礎・境界 J82-A(2)，pp.209～217， 1999.2

9) T.Umemoto,Doi,Yamagiwa,S.Umemoto,:An Application of the frequency analysis type adaptation algorithm to vibration control, SICE Annual Conference in Fukui,August.4-6,2003,Fukui University,Japan 10) 岡口,薮野,梅本:適応フィルタを用いた反共振点の操作による非線形往復 振動系の制振, 日本機械学会論文集 (C 編),74 巻 742 号,pp.1416 $1422,2008.6$

11)前川,森本,坂上:建築・環境音響学 第二版,共立出版株式会社,p.7,2004.9 


\section{THE REDUCTION EFFECT OF CONSTRUCTION MACHINERY NOISE BY FEEDFORWARD TYPE ACTIVE NOISE CONTROL}

\section{Laura KANAZAWA*, Kenji YASUI ** and Katsuo YAGINUMA***}

\footnotetext{
* Senior Research Engineer, Architectural Research Division, Technical Research Institute, Okumura Corporation, M.Art Eng. ** Planning Team Leader, Plans and Management Division, Technical Research Institute, Okumura Corporation *** Senior Research Engineer, Architectural Research Division, Technical Research Institute, Okumura Corporation, M.Eng.
}

The construction machineriy noises have a sound peak in low frequency region(approximately less than $100 \mathrm{~Hz}$ ). Active noise control (in the following, ANC) is one of the methods to reduce the low frequency noise. ANC is a system that reduce noises by interference between noise and sound wave from a speaker that has reverse phase against the noise. In recent years,ANC is occasionally applied to reduce noise of construction machineries like backhoes and rough terrain cranes.

As usual, the control method of the ANC is feedback that has only error microphone,or feedforward that has the reference microphone and the error microphone. In the construction sites, there are many kinds of noise sources like backhoes,cranes,power generator,roadheader,etc., therefore the ANC using feedback control may lose the target noise. Also, most of construction machineries move around in the construction site during operation,for safety it is hard to set up two microphones on the machineries for feedforward control.

So we developed an active noise control system for noise of construction machineries that can be set up on moving noise source like backhoes and can control stably. We considered about the applicability of the feedforward control which uses only reference signal, uses no $\hat{\mathrm{C}}$. Then, we proposed control methods of the ANC which estimate a predominant frequency and calibrate an amplitude ratio and a phase delay in time domain.

To estimmate a dominant frequancy in time domain, the proposed control method uses the optimized filter of LMS algorism. The LMS algorism minimizes the difference of input signal and the band-pass- filtered signal in the ANC system. The coefficient of the optimized filter is updated by each sampling time, the estimated frequency at $n+1(n$ means a time number. $n=1,2 \ldots)$ is mainly derived from the estimated freqency at $n$, and the ratio of the coefficient of the optimized filter at $\mathrm{n}+1$ to the coefficient of the optimized filter at $\mathrm{n}$.

As for the calibration of an amplitude ratio and a phase delay in time domain, the proposed control method uses correction values of amplitude and phase delay in each frequency, which are obtained in advance from the comparison o of the input signal and the output signal of the ANC system. When the control starts, at first, the system takes out the correction value of the estimated frequency. Next, the system subtracts the number of data of the correction value from the number of data of one wavelength for the estimated frequency. At last, the system takes out the past data at the point of calculated difference from the start point, and the data multiply by the correction value of amplitude is the output signal.

To confirm the usefulness of the proposed method, we carried out numerical simulations. In the simulation, we used some fixed sin waves of $50 \mathrm{~Hz}$ to $100 \mathrm{~Hz}$, and fluctuated sin waves such as $40 \mathrm{~Hz}$ to $50 \mathrm{~Hz}$ or $40 \mathrm{~Hz}$ to $100 \mathrm{~Hz}$, as input signal. As a result, the proposed methods can control stably and the control speed of proposed method is faster than that of conventional feedforward control and conventional feedback control.

Then, we carried out experiments in a laboratory to verify the effectiveness of ANC system using proposed method.Some fixed sin waves of $50 \mathrm{~Hz}$ to $100 \mathrm{~Hz}$ and construction machinery noises are used as input signal. As a result, the ANC reduced fixed sine waves by maximum about $20 \mathrm{~dB}$, and the ANC reduced construction machinery noise by about $10 \mathrm{~dB}$ 